\title{
RUBUS FLORA OF THE DUROWO FOREST DISTRICT (NORTHERN WIELKOPOLSKA, POLAND)
}

\author{
Monika GAPIŃSKa, PIOTR KosińSKI
}

\begin{abstract}
M. Gapińska, P. Kosiński, Department of Botany, Poznań University of Life Sciences, Wojska Polskiego 71 C, 60-625 Poznań, Poland.

P. Kosiński, Institute of Dendrology, Polish Academy of Sciences, Parkowa 5, PL-62-035 Kórnik, Poland, e-mail: kosinski@man.poznan.pl
\end{abstract}

(Received: December 1, 2016. Accepted: December 20, 2016)

\begin{abstract}
AвSTRACT. The Rubus flora of northern Wielkopolska (Greater Poland) is not yet fully discovered, but the recent studies on the genus Rubus suggest that it is clearly not as rich as in case of southern Wielkopolska. The results of the field observations show that the area of the Durowo Forest District contains 14 representatives of the genus Rubus, out of which the presence of four taxa has already been reported and confirmed. Only Rubus czarnunensis, species endemic to Poland and mentioned in this area in the early 20th century, was not rediscovered. The presence of two species, previously unknown in this area, $R$. nemoralis and $R$. seebergensis, have shifted their range limits by $16 \mathrm{~km}$ and $30 \mathrm{~km}$ to the north, respectively. A statistically significant higher number of bramble species occurred in pine forest growing on fertile deciduous forest habitats.
\end{abstract}

KEY WORDS: chorology, geographical distribution, range limits, occurrence condition

\section{INTRODUCTION}

In Poland, there is a comprehensive elaboration on the taxonomy and chorology of the genus Rubus by ZIELIŃSKI (2004). On a more local scale, the brambles continue to remain a fairly unknown constituent of the forest, however, considering the number of taxa, it is not uncommon for them to be the main component of woody flora of such communities. Over a decade from the release of the monograph of the genus Rubus in Poland, 14 more species were added to the 92 which were already covered by the book (ZIELIŃSKI 2004). This number includes five species considered to be unknown to science (ZIELIŃsKI et al. 2004b, ZieLIŃSKI \& TRÁVNIČEK 2004, TRÁVNIČEK et al. 2005, MALiŃski et al. 2014, Wolanin et al. 2016), as well as nine species previously unknown in Poland (KosińsKi \& BEDNoRZ 2003, ZIELIŃSKI et al. 2004a, b, ZielińsKi \& TrÁvNIČEK 2004, KosińsKi \& OKLEJEWICZ 2006, Kosiński 2006, 2010, KosińsKi \& ZiELIŃSKi 2013, OKLejewicz et al. 2013, KosińSKI et al. 2014, MALIŃSKI et al. 2015).

The contemporary research on Rubus flora in Wielkopolska was focused on the southern part of the region, where a total of 54 species of the genus Rubus were observed (MALIŃski 2001). The Rubus flora of northern Wielkopolska appears to be distinctly less numerous: the herbarium collections from the ATPOL BC and CC squares $\left(20000 \mathrm{~km}^{2}\right)$, which contain the area of research, encompass 29 taxa. The reason for this might be the lack of more complex research on brambles performed in this part of Poland. Sample data on this topic is derived primarily from areas falling under various forms of nature protection, or such for which exclusive floristic elaborations were created. In areas neighbouring the Durowo Forest District, a relatively high amount of information regarding the occurrence of brambles comes from the Landscape Park Zielonka Forest, as well as from the eastern part of Gniezno Lake District.

The purpose of the study was to learn about the species richness, distribution and conditions of occurrence of the representatives of the genus Rubus in the area of Durowo Forest District, which should at least partially allow to fill the gap in the knowledge of the bramble flora of the northern parts of Wielkopolska. 


\section{RESEARCH AREA}

The study area is located within four administrative districts: Chodzież, Gniezno, Oborniki and Wągrowiec (Fig. 1). According to the physico-geographical regionalization, it is situated in the Chodziez and Gniezno Lake Districts mesoregions belonging to the Wielkopolska Lake District macroregion (KONDRACKI 2014). A part of the Durowo Forest District is the area of protected landscape "Wełna River Valley and Gołańcz-Wągrowiec channel". The "Wełna River Valley" is also included in the habitat protection NATURA 2000 PLH300043 (BATOR et al. 2014).

The terrain is predominantly flat, with several undulating or hilly places in the south-eastern part. The altitude differences on the surface in the middle and western part do not exceed $5 \mathrm{~m}$. The lowest place $(67 \mathrm{~m})$ is located in the western part of Wełna River Valley, whereas the highest point $(129.6 \mathrm{~m})$ is locat- ed in the Gołaszewo forest range (Plan URZĄDZENiA LASU... 2011).

The major part of this area is used as agricultural crops. Forests account for about $14 \%$ of the area. The largest area is occupied by deciduous forest habitats $(69 \%)$, and fresh mixed broadleaved forests prevail among them $(32.8 \%)$. Coniferous forests are represented mostly by fresh mixed coniferous forests (24.9\% of forest area).

In the locations covered by this research, rusty soils were the dominant type, and they were represented mainly by haplic brunic arenosols (34.2\%) and brunic arenosols (26\%). The following types of soils occurred less frequently: luvisols (8.2\%), mollic gleysols dystric (5.5\%), podzols $(5.5 \%)$, umbric gleysols $(4.1 \%)$ and phaeozems (4.1\%), whereas other types of soils had a marginal presence (BANK DANYCH O LASACH... 2016).

The climate in this area is shaped by the polar-oceanic air masses. The average amount of rainfall is

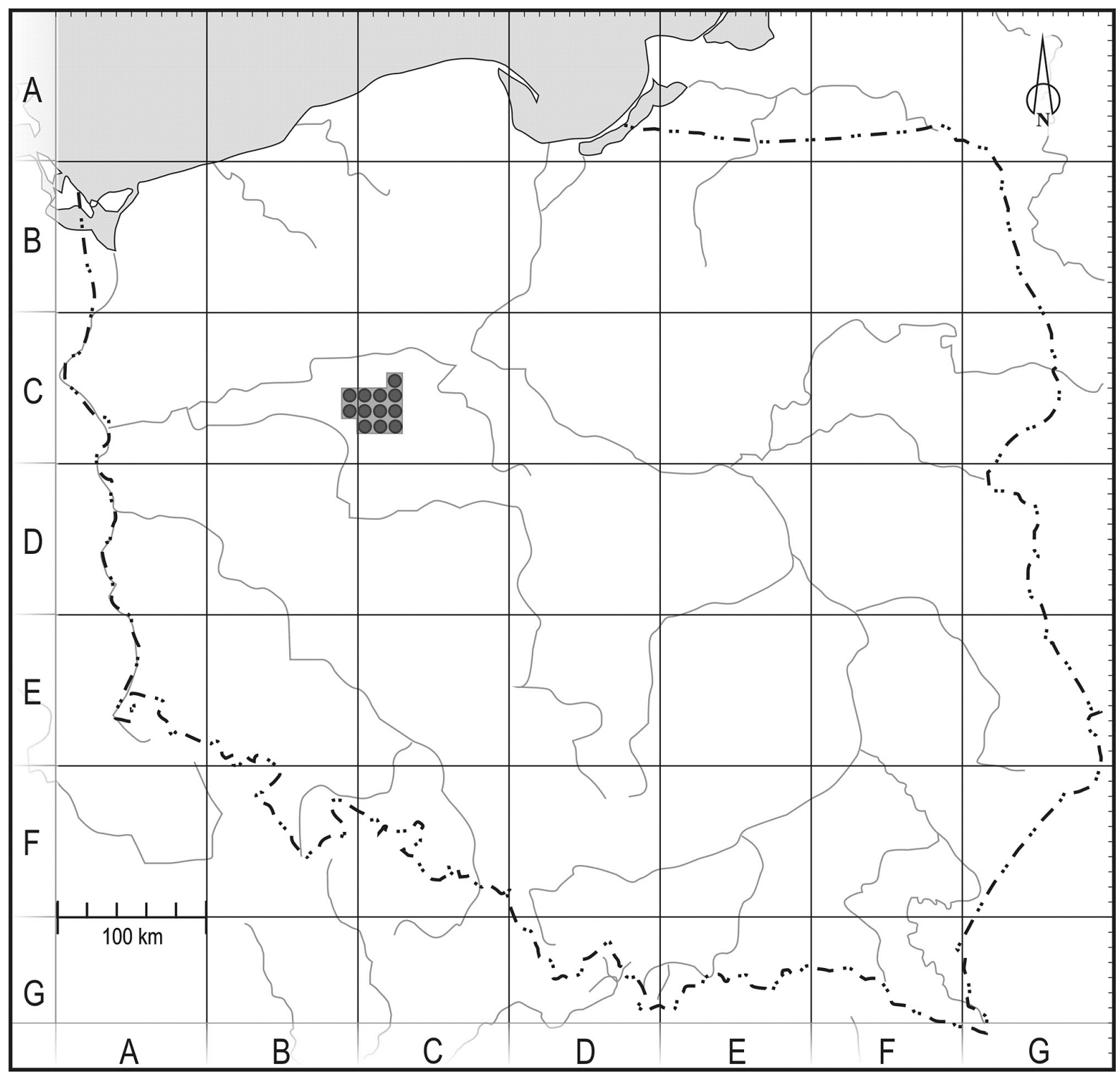

Fig. 1. Study area (ATPOL grid) 
530-550 mm per year. Winter usually lasts 75 days, including 52 days with snow cover. The length of the growing season is about 215 days, summer usually lasts 98 days. The average temperature in summer is $17.8^{\circ} \mathrm{C}$ (Plan Urządenia Lasu... 2011).

\section{METHODS}

The primary source of information regarding the contemporary bramble flora was the field research conducted since the second half of July 2016 to October 2016. Data encompassing 233 records was collected from a total of 80 locations. Historical data in the form of herbarium materials, consisting of a total of 13 records regarding the presence of five species (KOR, POZ and WRSL), was included as well. An area of about 1 hectare, within a specific sub-compartment, was considered as a single location. Observations regarding each stand were documented with a list of Rubus species along with estimations of their abundance in accordance with a six-level number/percent scale: 1 - a few (1-3 specimens/ramets per location), 2 - several (4-10 specimens/ramets), 3 - over a dozen (11-20 specimens/ramets), 4 - many (more than
20 specimens/ramets or $5-15 \%$ coverage), 5 - numerous (16-30\% coverage), 6 - common (more than $30 \%$ coverage). The habitat data (soil types, habitat types of forests, forest stand age and composition) was derived from the Forest Data Bank (BANK DANYCH o LASACH... 2016). Taxonomic nomenclature and information concerning the general range of Rubus species are based on Atlas Florae Europaeae (KURTTO et al. 2010), and the data regarding their distribution in Poland were derived from the work of ZIELIŃSKI (2004). The grid of $1 \times 1 \mathrm{~km}$ squares, in accordance with the principles outlined in the Atlas of Distribution of Vascular Plants in Poland (ZAJĄC 1978), was carried on the maps. The map of concentration of species was prepared using inverse distance weighting (IDW) in the QGIS 2.18. software (QGIS DeVelopment Team 2016). The Chi-square test was conducted using the Past 3.14 software (HAMmer et al. 2001) in order to determine the relationships between different features of the habitat and the number of species in the stand. The current locations were marked on the species distribution maps using a black circlet $(\bullet)$, whereas the historical data were marked using grey diamonds $(\diamond)$.

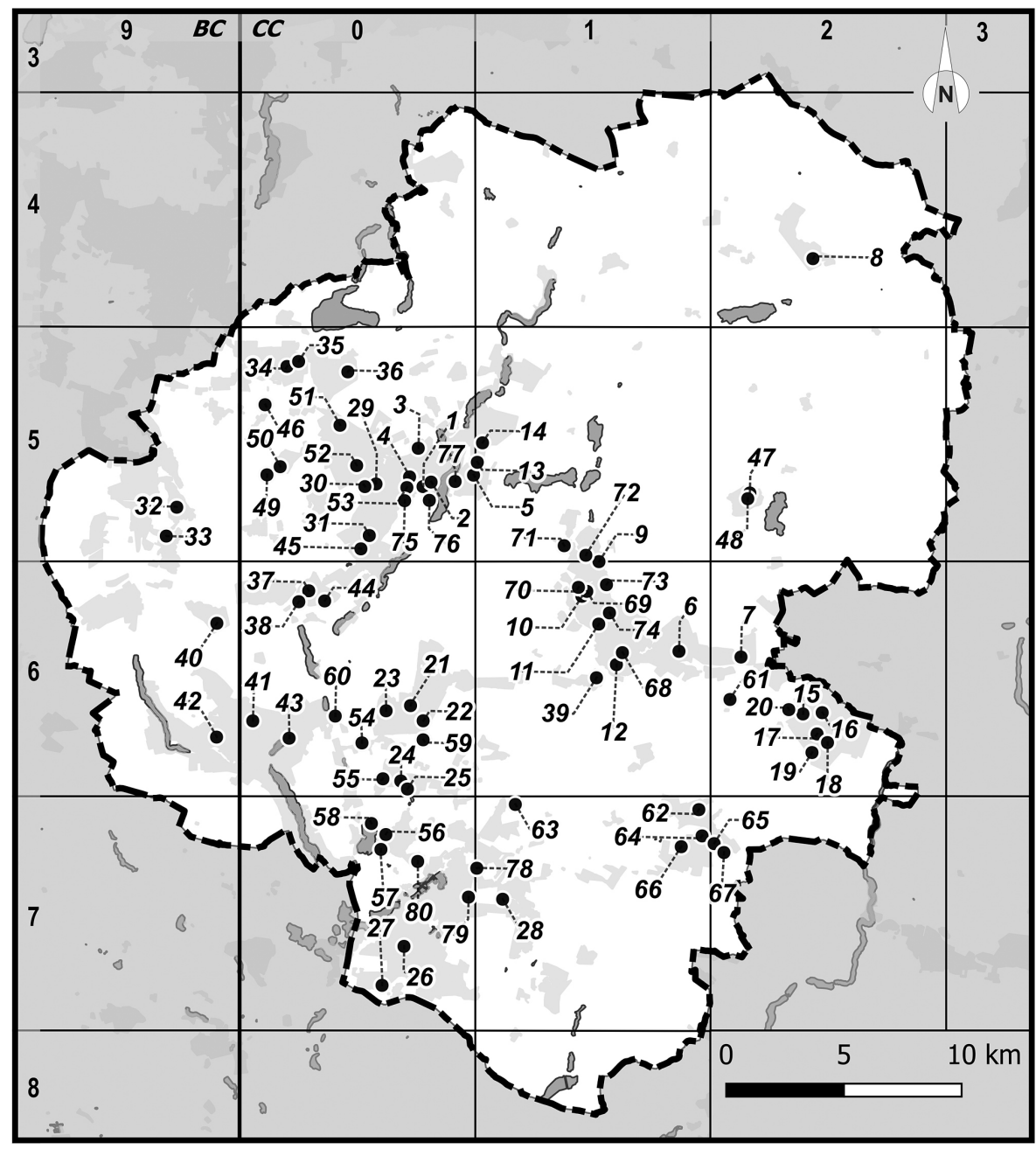

Fig. 2. Location of stands 
List of examined stands (Fig. 2). Order of the description: stand number, coordinates, forest subcompartment, forest habitat type. Abbreviations of forest habitat types: MCf - fresh mixed coniferous forest, $\mathrm{MCm}$ - moist mixed coniferous forest Cf - fresh coniferous forest, $\mathrm{MBf}$ - fresh mixed broadleaved forest, $\mathrm{MBm}$ - moist mixed broadleaved forest, Bf - fresh broadleaved forest, $\mathrm{Bm}$ - moist broadleaved forest, AA - alder-ash forest. Four stands marked with an asterisk $\left({ }^{*}\right)$ ware beyond the State Forests management.

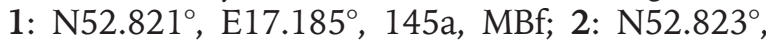
E17.19, 144f, MBf; 3: N52.836 ${ }^{\circ}, \mathrm{E} 17.181^{\circ}, 105 \mathrm{~b}$, MBf; 4: N52.825 ${ }^{\circ}$ E17.176 ${ }^{\circ} 146 \mathrm{~g}, \mathrm{Bf} ; 5: \mathrm{N} 52.826^{\circ}$, E17.216, $117 f$, Bf; 6: N52.761 ${ }^{\circ}$, E17.348, 319 c, Bm; 7: N52.759, E17.387 $, 312 \mathrm{~g}, \mathrm{MBf} ; 8$ : N52.912 ,

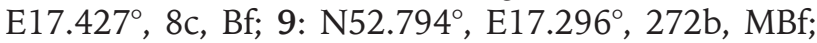
10: N52.781 ${ }^{\circ}, \mathrm{E} 17.286^{\circ}, 281 \mathrm{f}, \mathrm{Bf} ; 11$ : N52.771 ,

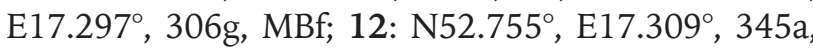

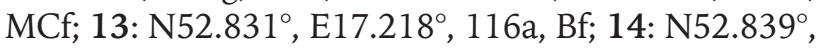

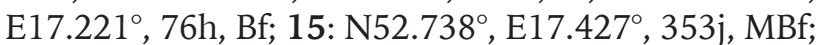
16: N52.739 ${ }^{\circ}$ E17.439 $, 358 \mathrm{~b}, \mathrm{Bm} ; 17$ : N52.73,

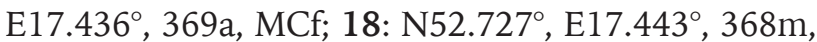

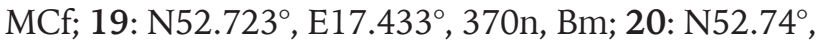
E17.418 $, 353 \mathrm{~g}, \mathrm{Bm} ; 21$ : N52.738 $, \mathrm{E} 17.18^{\circ}, 403 \mathrm{k}$, CF; 22: N52.732 ${ }^{\circ}, \mathrm{E} 17.188^{\circ}, 404 f, \mathrm{CF} ; 23: \mathrm{N} 52.735^{\circ}$,

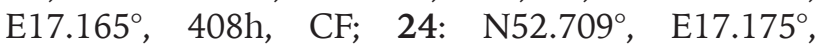
519f, MBf; 25: N52.706 ${ }^{\circ}$ E17.18 ${ }^{\circ}$, 518i, MBm;

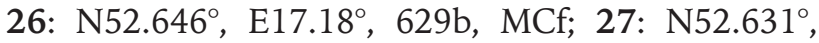

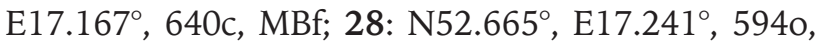
CF; 29: N52.822 ${ }^{\circ}, \mathrm{E} 17.155^{\circ}, 150 \mathrm{~b}, \mathrm{Bf} ; 30: \mathrm{N} 52.821^{\circ}$, E17.148 , 151a, MBf; 31: N52.802 ${ }^{\circ}$, E17.151 ${ }^{\circ}, 163 \mathrm{~h}$, MBf; 32: N52.811 ${ }^{\circ}, \mathrm{E} 17.03^{\circ}, 209 \mathrm{~h}, \mathrm{Bf} ; 33: \mathrm{N} 52.8^{\circ}$, E17.024 ${ }^{\circ}, 212 \mathrm{~b}, \mathrm{Bf} ; 34: \mathrm{N} 52.866^{\circ}, \mathrm{E} 17.097^{\circ}, 41 \mathrm{~m}$,

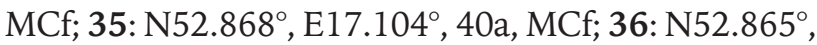
E17.135 ${ }^{\circ}$, 58b, MBf; 37: N52.781 ${ }^{\circ}$, E17.114 ${ }^{\circ}, 178 \mathrm{c}$, MCf; 38: N52.776 ${ }^{\circ}$, E17.108 ${ }^{\circ}$, 181f, MBf; 39: N52.75',

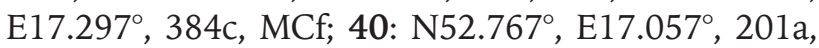
$\mathrm{Bm} ; 41$ : N52.73 ${ }^{\circ}, \mathrm{E} 17.081^{\circ}, 447 \mathrm{c}, \mathrm{MCm} ; 42: \mathrm{N} 52.724^{\circ}$,

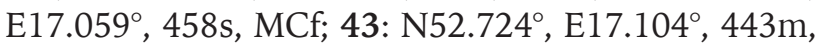

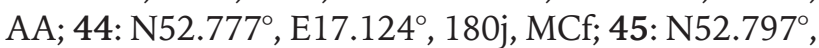

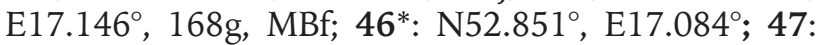
N52.822 ${ }^{\circ}$, E17.391 ${ }^{\circ}, 2611$, MBf; 48: N52.82 ${ }^{\circ}$, E17.389 ,

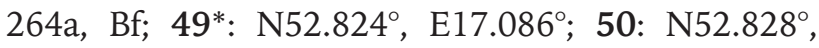

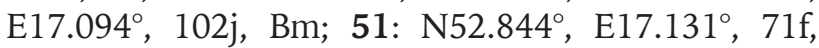

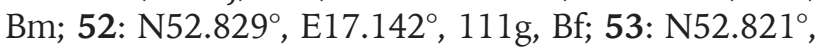
E17.174 $, \quad 147 \mathrm{~b}, \quad \mathrm{MBf} ; \quad 54: \mathrm{N} 52.723^{\circ}, \mathrm{E} 17.15^{\circ}$, 510b, MBf; 55: N52.709 ${ }^{\circ}$ E $17.164^{\circ}$, 520j, MBf; 56: N52.688 ${ }^{\circ}, \mathrm{E} 17.167^{\circ}, 568 \mathrm{k}, \mathrm{MBf} ; 57$ : N52.682 ${ }^{\circ}$,

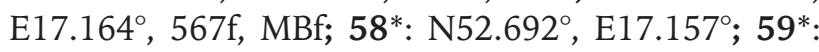

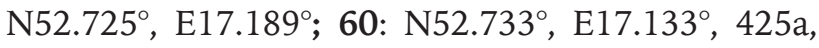

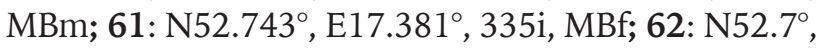
E17.362 ${ }^{\circ}, 532 \mathrm{i}, \mathrm{Bf} ; 63$ : N52.701 ${ }^{\circ}$, E17.248 ${ }^{\circ}, 546 \mathrm{a}, \mathrm{Bm}$; 64: N52.691 ${ }^{\circ}, \mathrm{E} 17.365^{\circ}, 535 \mathrm{~g}, \mathrm{MBf} ; 65$ : N52.688 , E17.373, 537c, MCf; 66: N52.686 ${ }^{\circ}, \mathrm{E} 17.352^{\circ}, 540 \mathrm{~d}$, MBf; 67: N52.684 ${ }^{\circ}$ E17.379 ${ }^{\circ}$ 5361, MBf; 68: N52.76 ,

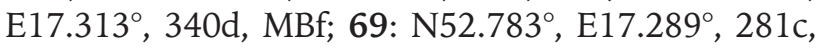

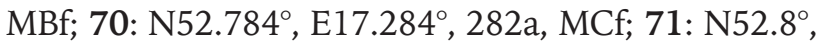

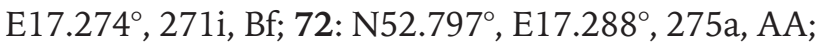

73: N52.786 $, \mathrm{E} 17.302^{\circ}, 278 \mathrm{~b}, \mathrm{MBf} ; 74: \mathrm{N} 52.775^{\circ}$,

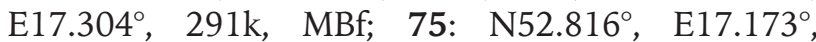

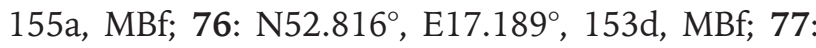
N52.824 ${ }^{\circ}, \mathrm{E} 17.205^{\circ}, 142 \mathrm{a}, \mathrm{Bf} ; 78: \mathrm{N} 52.676^{\circ}, \mathrm{E} 17.224^{\circ}$,

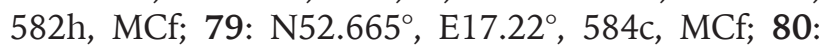
$\mathrm{N} 52.678^{\circ}, \mathrm{E} 17.187^{\circ}, 574 \mathrm{~h}, \mathrm{Bf}$.

\section{RESULTS}

The contemporary bramble flora of Durowo Forest District consists of 14 taxa. The observations have proven the occurrence of four species found previously: $R$. nessensis, $R$. plicatus, $R$. $\times$ pseudidaeus and $R$. saxatilis. No specimens of $R$. czarnunensis, which is an endemic species of Poland mentioned in this area in the early 20th century (SPRIBILLE 1902), were found.

\section{CLASSIFICATION SCHEME OF RUBUS FLORA PRESENT IN THE RESEARCH AREA}

Genus: Rubus

Subgenus: Cylactis

Series: Saxatiles Rubus saxatilis L.

Subgenus: Idaeobatus Rubus idaeus L.

Subgenus: Rubus

Section: Rubus Subsection: Rubus

Series: Nessenses Rubus nessensis W. Hall

Series: Rubus Rubus plicatus Weihe \& Nees

Series: Rhamnifolii Rubus nemoralis P.J. Müller Rubus gracilis J. Presl \& C. Presl

Series: Sprengeliani Rubus sprengelii Weihe

Series: Vestiti Rubus pyramidalis Kaltenb.

Series: Radulae Rubus radula Weihe

Series: Glandulosi Rubus pedemontanus Pinkw.

Section: Corylifolii

Series: Sepincoli Rubus czarnunensis (Sprib.) Sprib.

Series: Subthyrsoidei Rubus gothicus Frid. \& Gelert

Series: Hystricopses Rubus seebergensis Pfuhl ex Spirib.

Section: Caesii Rubus caesius L.

Nothosubgenus $\times$ Idaeorubus Rubus $\times$ pseudoidaeus (Weihe) Lej. $(=R$. idaeus $\times R$. caesius $)$ 


\section{SPECIES OVERVIEW}

\section{Rubus caesius (Fig. 3)}

A species with an Euro-Siberian distributional range, with the centre in Europe, common in entire Poland. Detected in 44 locations (55\%) in the research area, mainly on roadsides, forests and riparian forests, and humid fresh and forests.

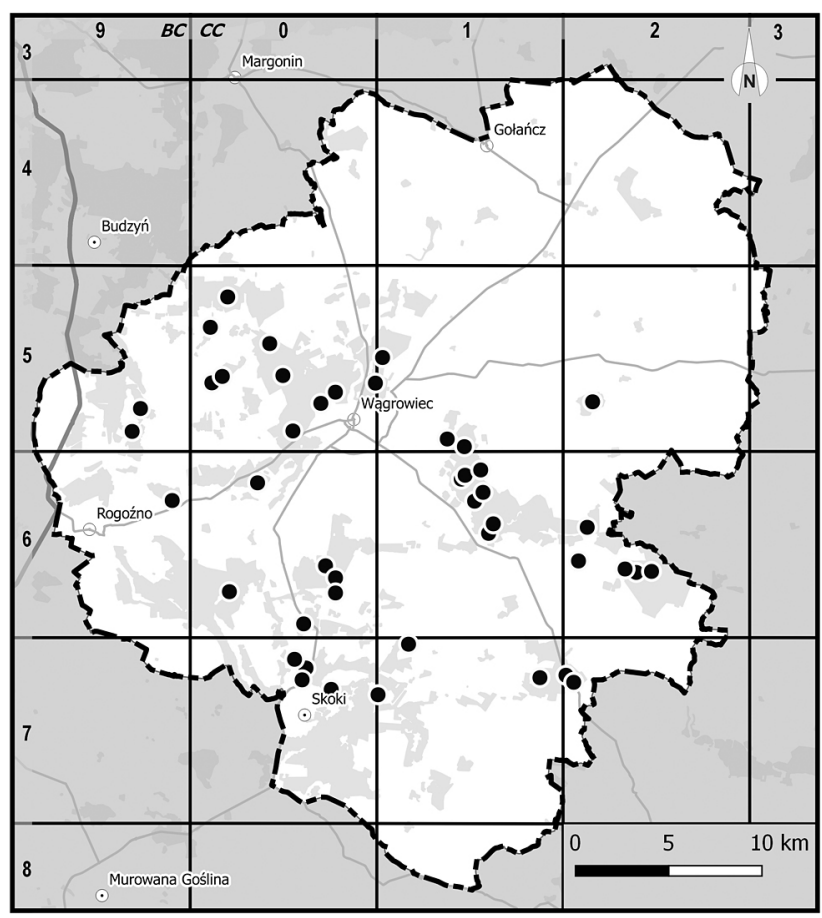

Fig. 3. Distribution of Rubus caesius in the Durowo Forest District

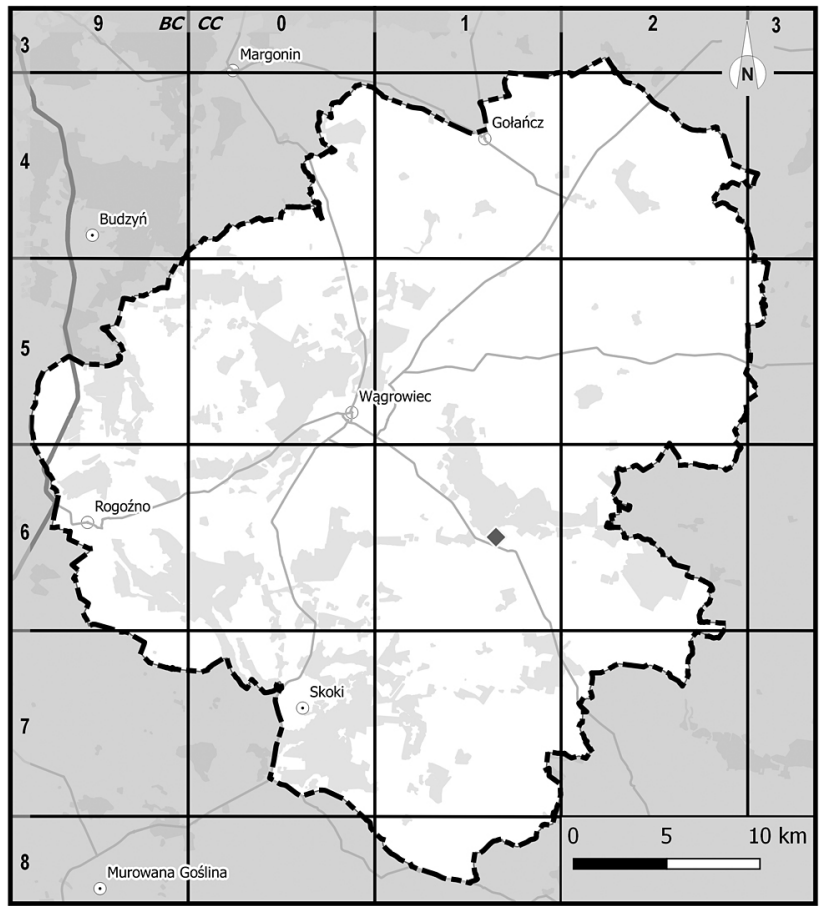

Ryc. 4. Distribution of Rubus czarnunensis in the Durowo Forest District

\section{Rubus czarnunensis (Fig. 4)}

An endemic species to Poland, occurring mostly in the northern Wielkopolska. Reported in one location, north-east from the town of Mieścisko (SPRIBILLE 1902), not confirmed later point of time, not found during the field research (this is the southernmost place of reported occurrence of this species).

3. Rubus gothicus (Fig. 5)

Central European species, distributed in southern Scandinavia, Denmark, Germany and western and north-western Poland. Previously not reported in the study area. During the research, this species was detected in seven locations $(8.8 \%)$, mainly on roadsides in moist and fresh deciduous forest habitats.

4. Rubus gracilis (Fig. 6)

Central European species, commonly found in the southern half of Poland. Previously not reported in the research area. During the field study, this species was found in 10 locations (12.5\%), mainly in mixed coniferous and deciduous forest habitats.

5. Rubus idaeus (Fig. 7)

Circumboreal species; the typical subspecies $(R$. idaeus subsp. idaeus) is present in Europe and western Asia. The most common representative of the genus Rubus in the research area (78 records, $97.5 \%$ of locations). Common species, ubiquitous, growing regardless of the environmental conditions.

6. Rubus nemoralis (Fig. 8)

A species quite common in the north-east Europe, in Poland mostly present in the eastern parts of the Wielkopolska and Lower Silesia. Previously not reported in the study area (the nearest known location is in the Zielonka Forest). During the field research,

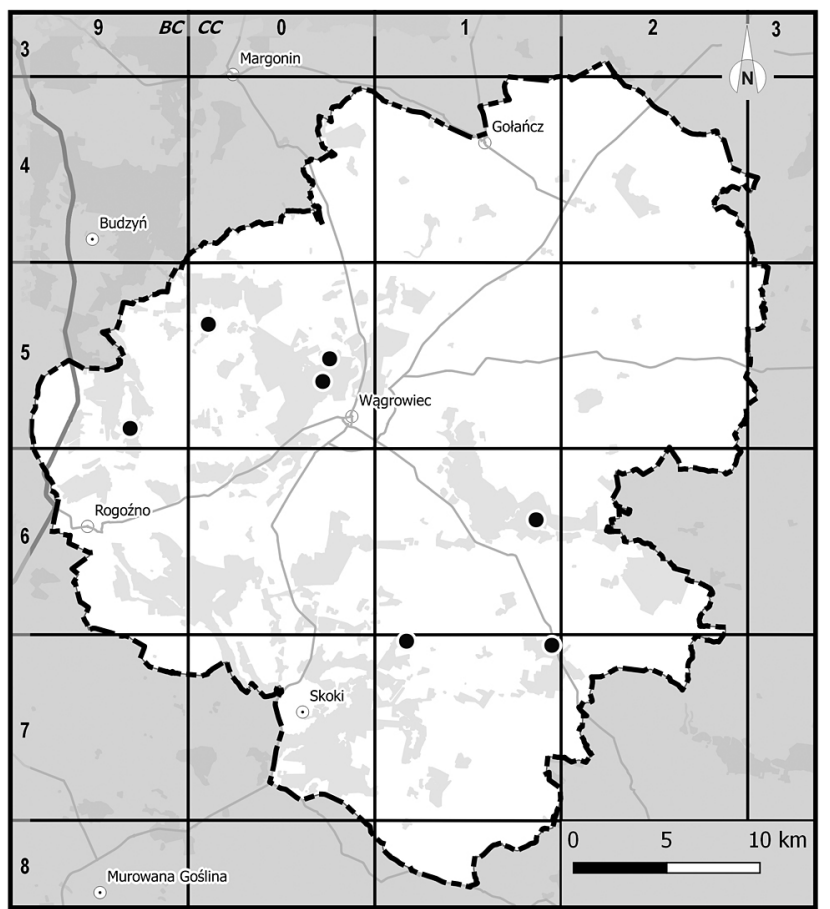

Ryc. 5. Distribution of Rubus gothicus in the Durowo Forest District 
this species was detected in one location, in a mixed fresh coniferous forest habitat. This expands the current northern distributional range of this species by $16 \mathrm{~km}$ (in the eastern part of the range).

7. Rubus nessensis (Fig. 9)

European species (central, north-western and eastern part of the continent). It occurs throughout Poland, however it might be locally rare. So far, re-

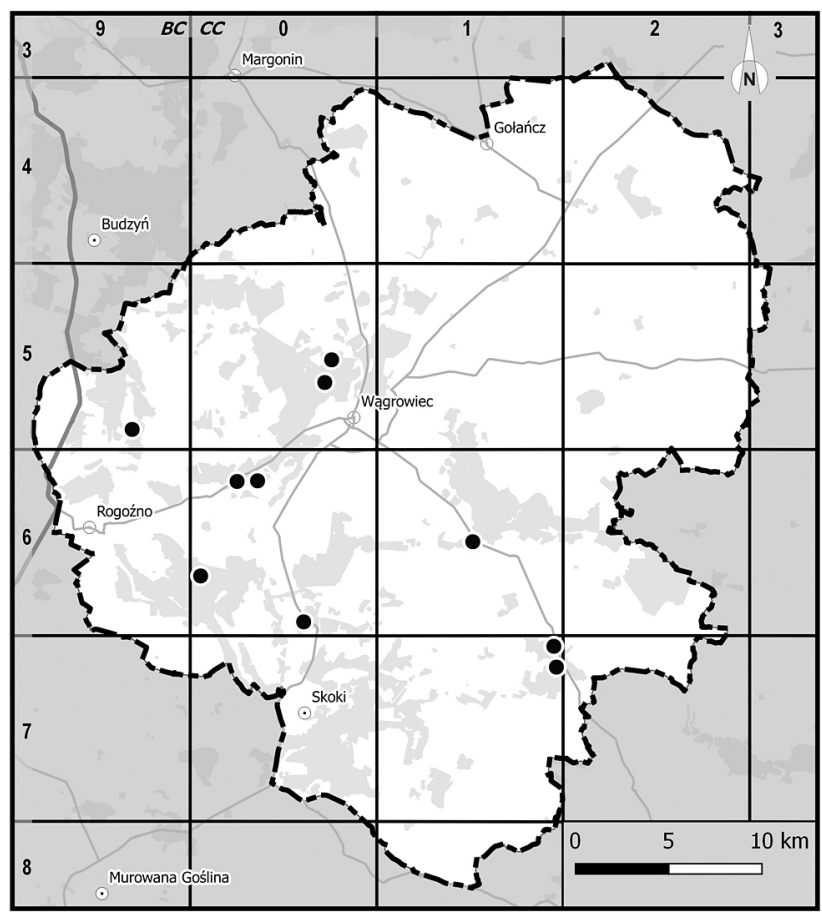

Ryc. 6. Distribution of Rubus gracilis in the Durowo Forest District

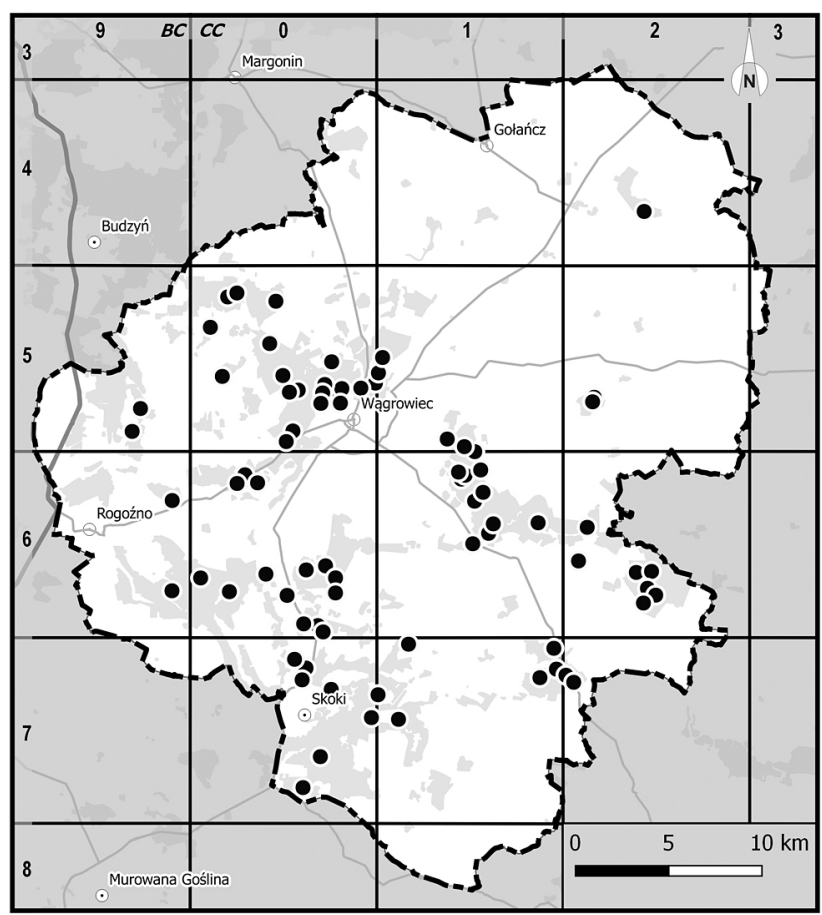

Ryc. 7. Distribution of Rubus idaeus in the Durowo Forest District ported in two locations in the research area: near Wagrowiec and Marlewo (Szostak 1975, KOR; Stefanek 1977, KOR). The species was observed in four stands $(5 \%)$ in mixed fresh coniferous forest and mixed deciduous forest habitats.

8. Rubus pedemontanus (Fig. 10)

Central European species (north-west and central part of the continent); in Poland it can be found pri-

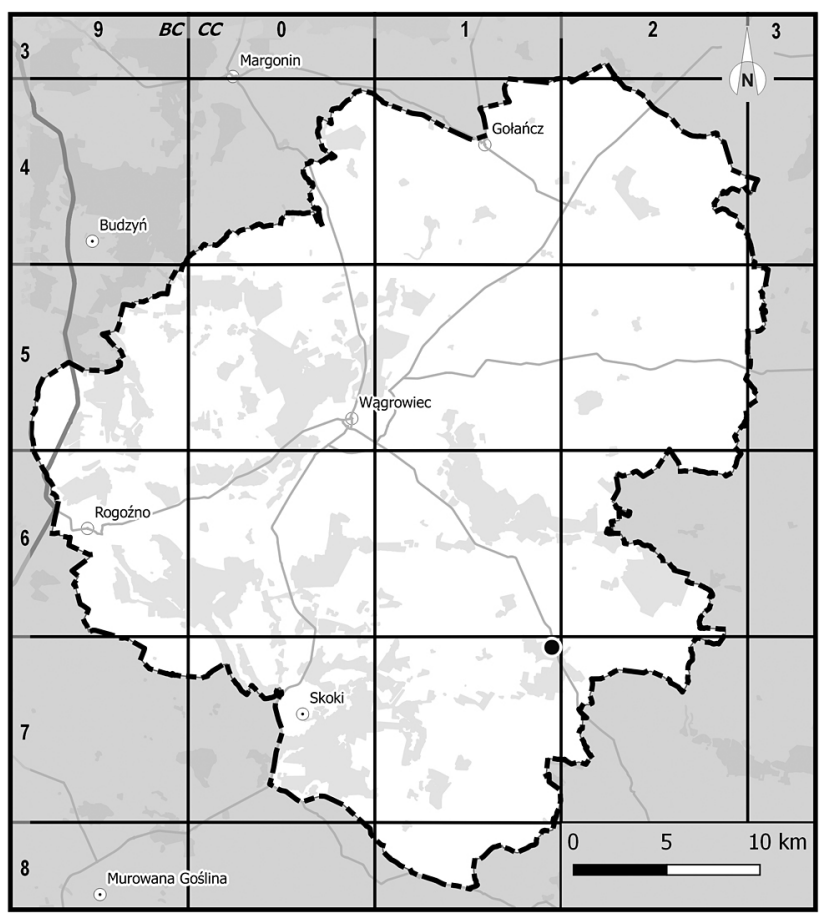

Ryc. 8. Distribution of Rubus nemoralis in the Durowo Forest District

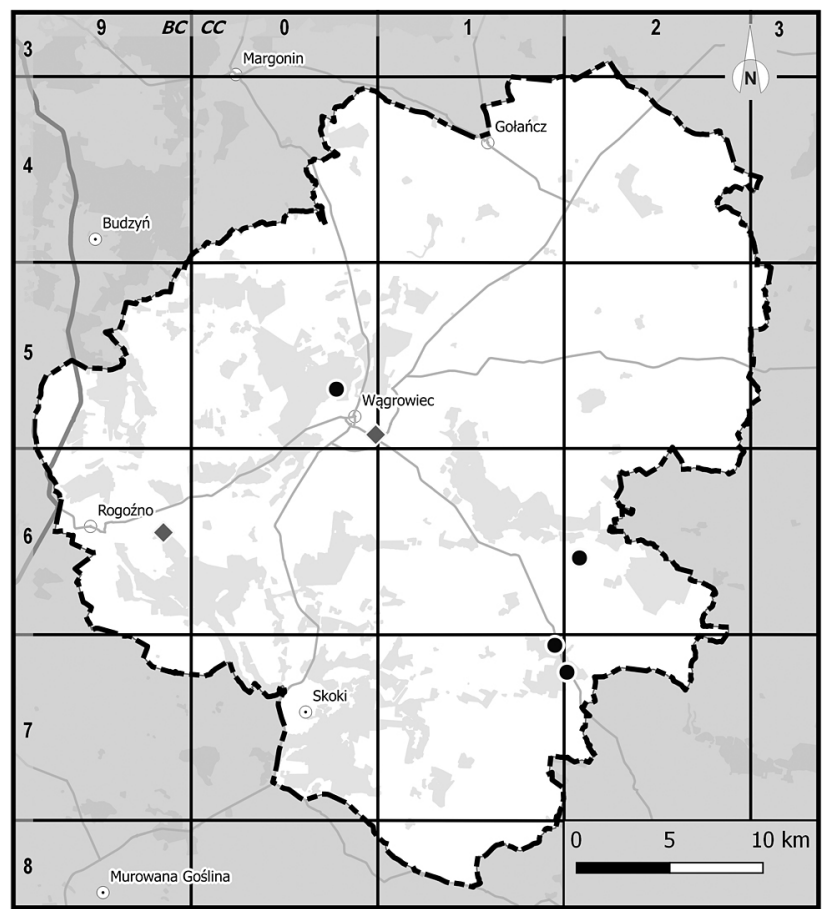

Ryc. 9. Distribution of Rubus nessensis in the Durowo Forest District 
marily in the south and north. Otherwise scattered. Previously unknown in the research area. Detected in one location, in a fresh broadleaved forest habitat.

9. Rubus plicatus (Fig. 11)

European species (north-western and central Europe); one of the most common bramble species in Poland, less frequently reported in south-west and north-east parts of the country. The second most

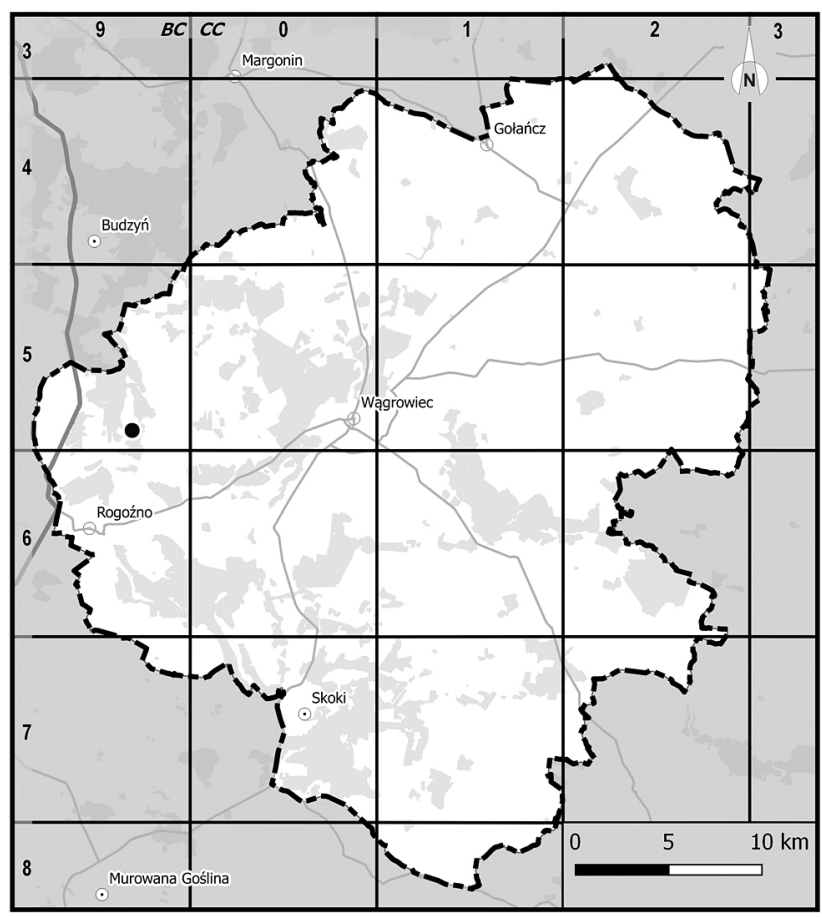

Ryc. 10. Distribution of Rubus pedemontanus in the Durowo Forest District

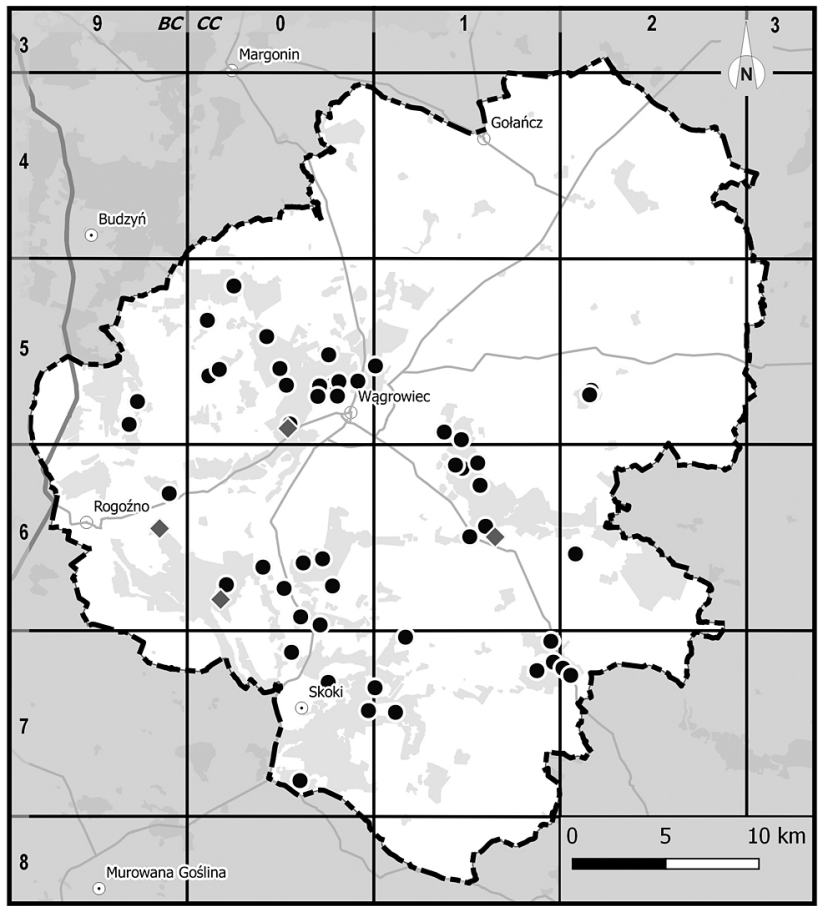

Ryc. 11. Distribution of Rubus plicatus in the Durowo Forest District common member of the genus Rubus (after raspberry) in the research area (50 records, $62.5 \%$ of locations), growing in various habitats. Previously reported in four different places: south-west from Przysieka (Boratyński 1974, KOR 6269), $3 \mathrm{~km}$ south from Rąbczyn (Boratyński 1974, KOR 6268), in the Dębina nature reserve (Szostak 1977, POZ), and in the vicinity of Marlewo (Stefanek 1977, KOR).

10. Rubus pyramidalis (Fig. 12)

A bramble distributed in the north-western and central Europe; in Poland: most commonly occurs in Wielkopolska and less frequently in Western Pomerania. Previously not reported in the study area. During the research, this species was found in one location, in a mixed fresh deciduous forest habitat.

11. Rubus radula (Fig. 13)

Central European species (western and central Europe); in Poland most common in Lower Silesia, Subcarpathia, Wielkopolska, and along the coast of the Baltic Sea. It was found for the first time in the study area, in one location in a fresh broadleaves forest habitat.

12. Rubus saxatilis (Fig. 14)

A perennial herbaceous plant of a Euro-Asian range; can be found in entire Poland, less frequent in the South-West and in the South. It was reported in five locations so far: Dębina (Szostak 1976, POZ), Wągrowiec (Szostak 1975, KOR 10998), Antoniewo (Fetsch 1969, KOR 10999), $2 \mathrm{~km}$ south-west from Rąbczyn (Boratyński 1974, KOR 6271) and $3 \mathrm{~km}$ south of Rąbczyn (Boratyński 1974, KOR 6270).

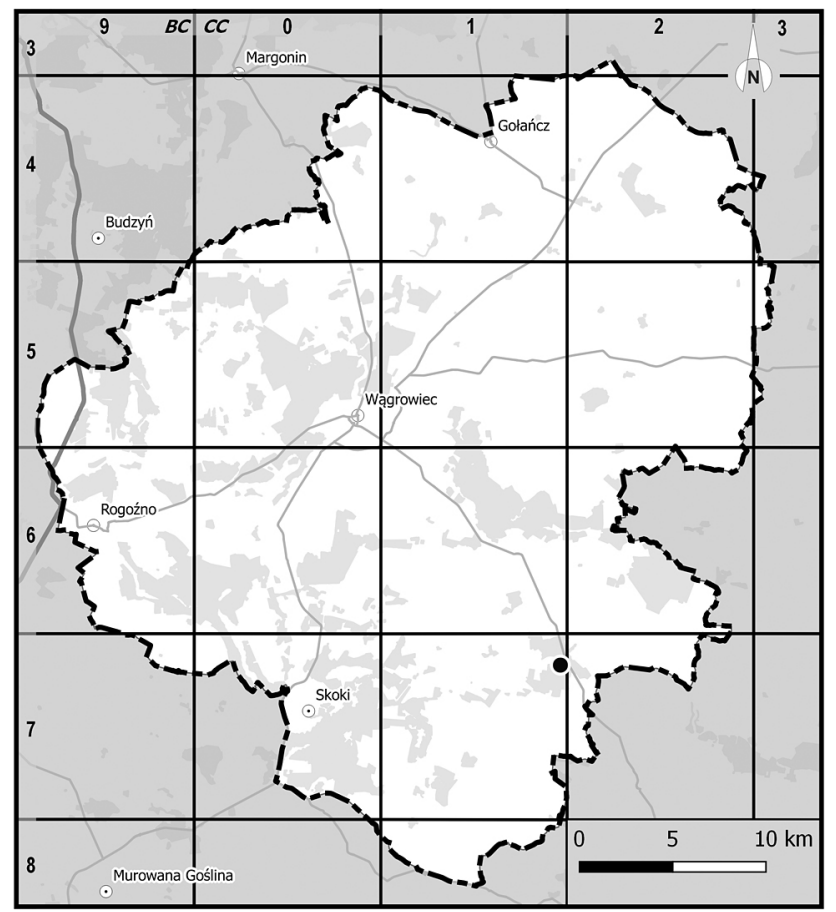

Ryc. 12. Distribution of Rubus pyramidalis in the Durowo Forest District 


\section{Rubus seebergensis (Fig. 15)}

An endemic species in Poland, commonly found in southern Wielkopolska, and in scattered locations in Lower Silesia. Previously not reported in this area. During the field study, this species was found in two locations which expand the current northern range of the species by $30 \mathrm{~km}$ (from the previously known locations in the Zielonka Forest). This bramble grows

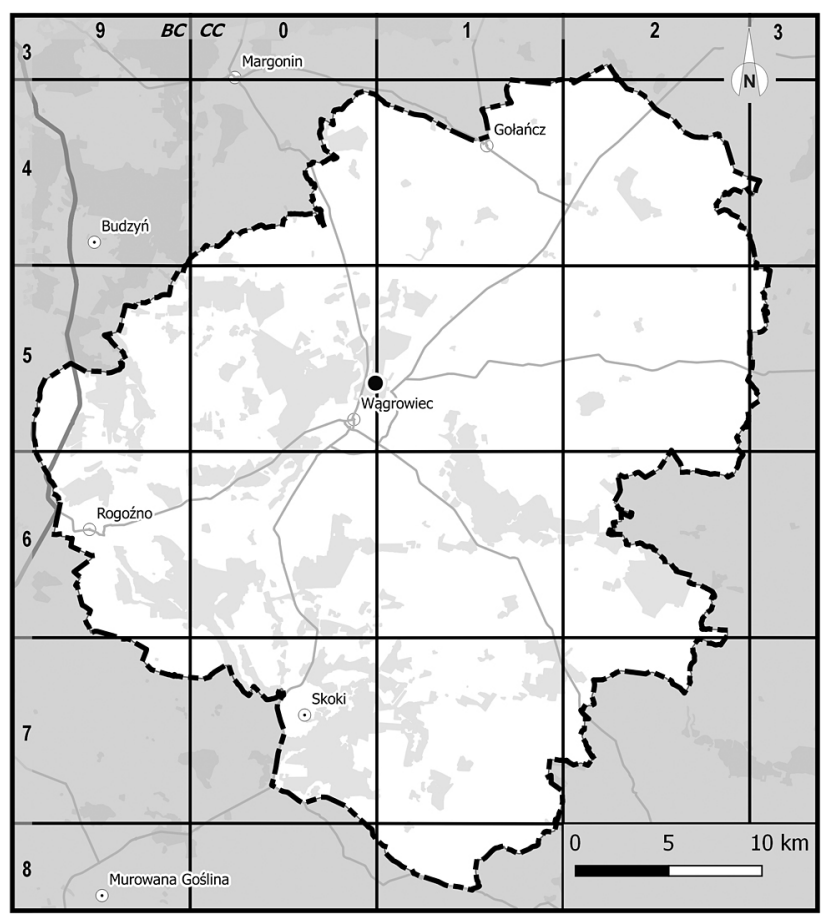

Ryc. 13. Distribution of Rubus radula in the Durowo Forest District

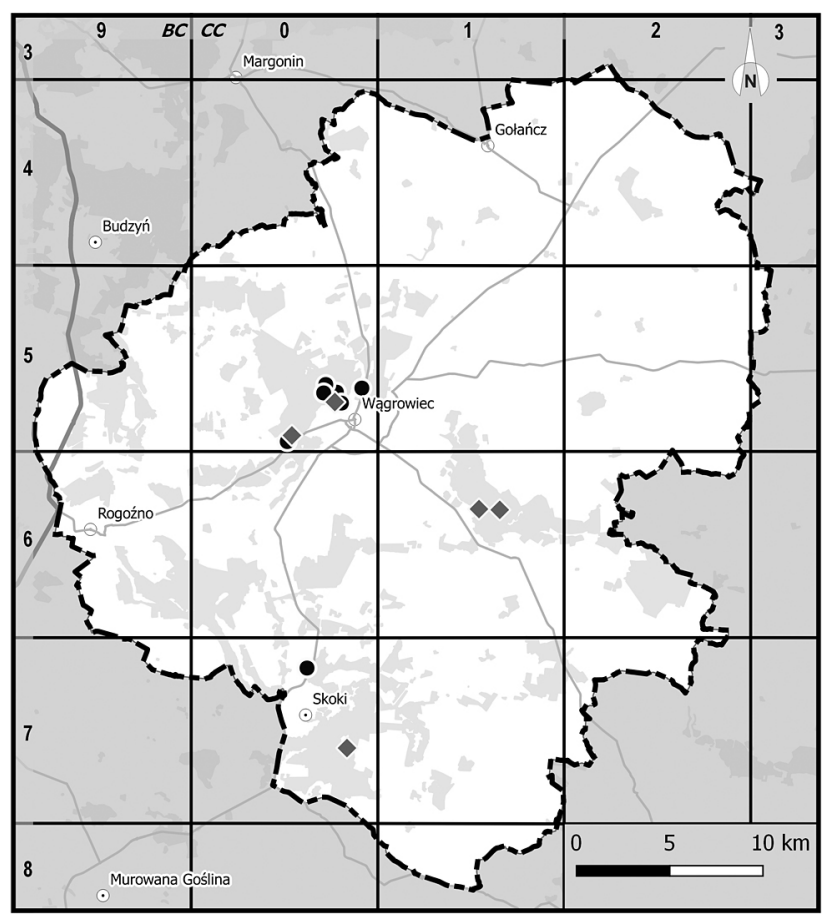

Ryc. 14. Distribution of Rubus saxatilis in the Durowo Forest District in fresh mixed coniferous forest and fresh deciduous forest habitats.

14. Rubus sprengelii (Fig. 16)

Central European species, in Poland mostly present in areas between the Vistula and the Odra rivers. Previously not reported in this area. During the research, this species was detected in 13 locations $(16.3 \%)$, mostly in fresh mixed forest habitat, and

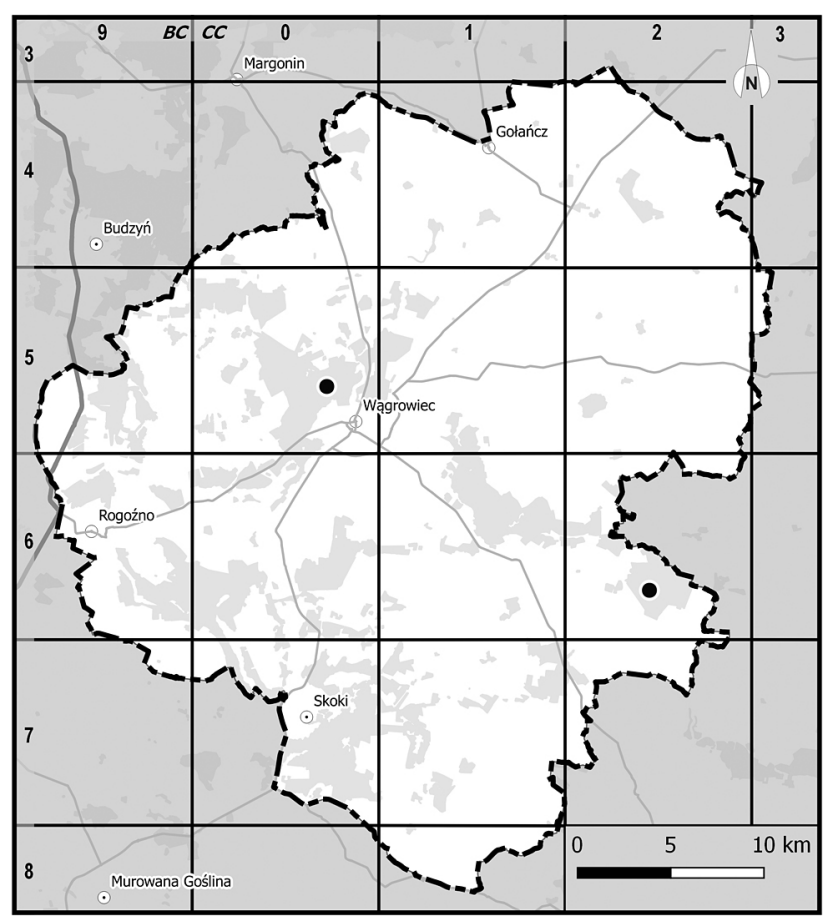

Ryc. 15. Distribution of Rubus seebergensis in the Durowo Forest District

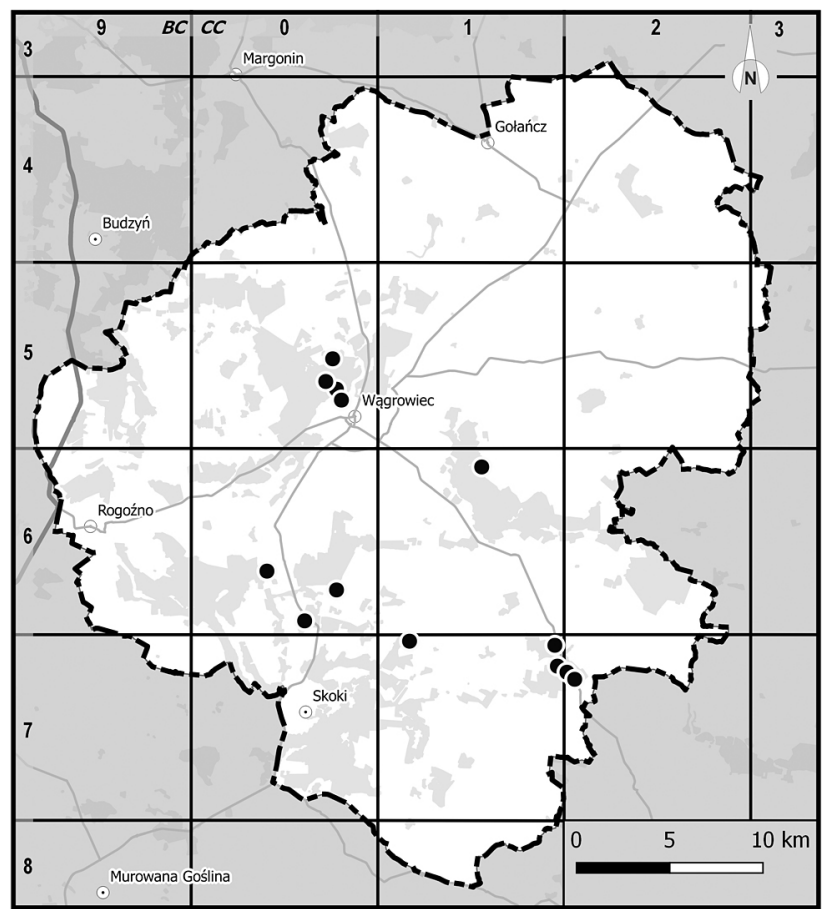

Ryc. 16. Distribution of Rubus sprengelii in the Durowo Forest District 


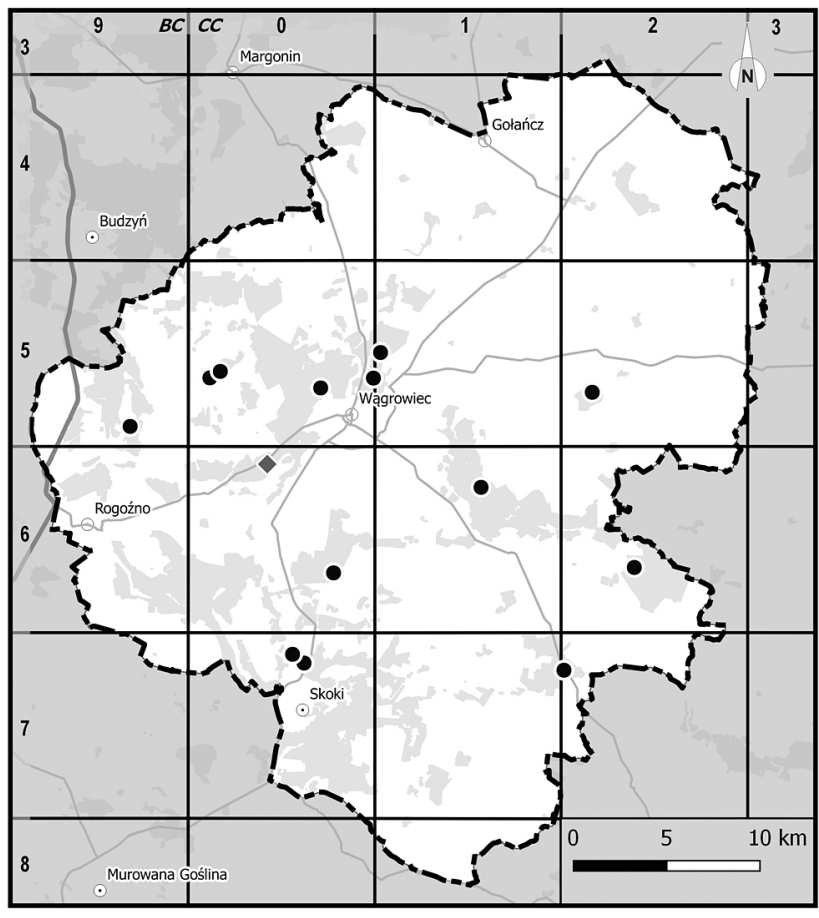

Ryc. 17. Distribution of Rubus $\times$ pseudoidaeus in the Durowo Forest District

less frequently in fresh mixed coniferous forest and fresh deciduous forest habitats.

\section{Rubus Xpseudoidaeus (Fig. 17)}

A taxon of a hybrid origin, formed as a result of interbreeding between the $R$. idaeus and $R$ caesius, which belong to different subgenera (Idaeobatus and Rubus, respectively), most often present in the places of abundant presence of the parent species, usually in synanthropic and disturbed habitats. Previously reported in one location near Wiatrowiec (Spribille 1898, KOR 10819 \& WRSL). During the research, the species was detected in 13 more stands $(16.3 \%)$.

\section{DISCUSSION AND CONCLUSIONS}

More than a half of the Rubus flora in the Durowo Forest District consists of very rare species (less than $5 \%$ of all surveyed locations): $R$. nemoralis, $R$. pyramidalis, $R$. radula, $R$. pedemontanus and $R$. seebergensis, as well as rare species (5-10\% of locations): $R$. nessensis, R. gothicus, R. saxatilis. Moderately common (11-20\% of locations) were the following species: $R$. gracilis, $R$. sprengeli and $R$. ×pseudoidaeus, whereas $R$. caesius, $R$. plicatus and $R$. idaeus were classified as common species (more than $50 \%$ of locations).

The distribution of the bramble species in the research area is not homogeneous. Three areas of species concentration can be identified (Fig. 18): 1) $0.7 \mathrm{~km}$ south-east of Potulice, north of Rogoźno; 2) $1 \mathrm{~km}$ south of Miłosławice, in the south-east part of the research area; and 3) north-west of Wagrowiec. The first case includes location no. 33, where eight species of bramble were detected. It was situated on

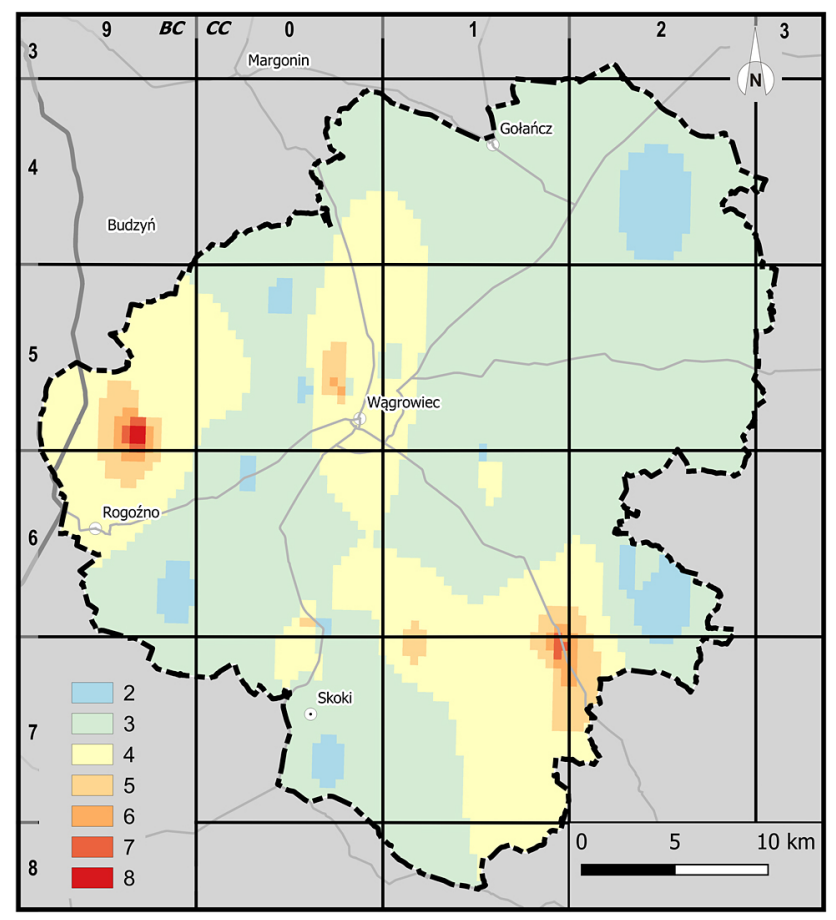

Fig. 18. Concentration of Rubus species in the Durowo Forest District

the edge of a 12-years-old forest plantation, primarily composed of pedunculate oak, in a fresh mixed forest habitat on brown deluvial soil. Stand no. 62 was the second largest location species-wise (7 species). It was located near Miłosławice, on brown soils, in a fresh deciduous forest habitat, occupied by a 124-year-old pine forest in the renewal phase, with underplanting. In the same forest complex, location no. 65 was also species-rich (6 species), placed on an umbric gleysols, in a moist deciduous forest habitat, on the edge of a barely 20-year-old forest plantation consisting of pines with a small admixture of birch trees. North-west of Wagrowiec, in both location no. 1 and 4, five species of the genus Rubus were detected. They occurred in pine monocultures (94- and 14 -year-old, respectively), in a fresh mixed coniferous forest habitat, on haplic brunic arenosols.

In order to find the answer to the question, which features of the habitat can affect the species richness present in a particular location, different variants of the available habitat information were tested which, due to the relatively small numbers of reported specimens, were combined into larger groups (e.g. forest habitat types were simplified to two categories: deciduous forest habitats and coniferous forest habitats; soils were divided into two groups of poor and fertile soils; Rubus species abundance of stands: into species-poor (up to 3 species) and species-rich (more than 3 species) stands. The independence tests of the above mentioned habitat features and stand species richness showed no statistically significant relations between these categories. 
An excessive growth of shrubs in the forests ecosystems is sometimes known as fruticetisation, and its more specific form concerning brambles - rubietisation (OlaczeK 1974). Such form of degeneration of the forest communities mostly affects the conifer monocultures established on fertile deciduous forest habitats or on former agricultural lands. On the basis of the acquired habitat information, and the current state and age of the forest stands (BANK DANYCH O LASACH... 2016), it was possible to accurately pinpoint the forest sub-compartments, in which this type incongruity occurred and to test the hypothesis of the lack of relation between the number of Rubus species in a given location and the mismatch between the type of forest stand and the type of habitat. Two types of forest stand/habitat type congruency were distinguished: 1) forest stands incompatible with the habitat type, which in most cases resulted in the domination of pines in the deciduous forest habitats, 2) forest stands more or less compatible with the habitat type, i.e. the dominance of conifer species in the coniferous forest habitats, or the dominance of deciduous species in the broadleaved forest habitats. By doing so, a $2 \times 2$ contingency table was prepared: a stand consistent with the habitat and containing 4-8 Rubus species (5 locations) or 1-3 species (37 locations); a stand incompatible with the habitat with 4-8 bramble species (13 locations) or 1-3 species (21 locations). A statistical analysis has shown the significant relations between the stand-habitat compatibility, and the number of Rubus species (Pearson's Chi-square: $7.21, \mathrm{df}=1, \mathrm{p}=0.007$, Monte Carlo $p=0.014$, Cramér coefficient $V=0.31$ ), which means that a higher number of bramble species was present in forest stands which were incompatible with the type of habitat.

The number of Rubus species detected in the Durowo Forest District (14 taxa) is relatively low, when compared with species richness of the regions in the south of Poland, e.g. in the Bardo Mts. (Central Sudetes), on a comparable area, the presence of 50 bramble species was confirmed (Kosiński 2010). During the research, as many as 10 new bramble species were found. Presumably, that is largely due to the lack of previous observations on the genus Rubus in this part of Wielkopolska. This is confirmed by the presence of $R$. caesius among the newly discovered species, which is widely known as one of the most common representatives of the genus Rubus in Poland. Furthermore, all new species, with the exception of $R$. pedemontanus, were previously known from the locations in the close proximity $(10-15 \mathrm{~km})$ from the borders of the Durowo Forest District. Additionally, in this area, there are other species, which were not detected within the borders of the Forest District: $R$. armeniacus Focke, $R$. apricus Wimm., $R$. fasciculatus P.J. Müll. and R. lamprocaulos G. Braun. The proximity of their stands suggests, that it is possible for those species to be present within the Forest District. In part, lack of them may be due to the specific nature of the research, which was focused on forests, hence the more synanthropic species, such as $R$. armeniacus and R. fasciculatus, occurring more frequently in the vicinity of the villages and/or on roadsides, may have been overlooked. Historical stand of $R$. apricus in the vicinity of the Zielonka Forest (Kulesza, 1930, POZnb) was the northernmost location of the species (both in Poland and throughout Europe), and was quite distinctly isolated from the main part of its range. This renders finding it in the area covered by the research highly unlikely. Rubus lamprocaulos is quite rare in region of Wielkopolska, however the possibility, that it is present in the Durowo Forest District, cannot be ruled out.

Among the group of species considered new in the research area, $R$. nemoralis and $R$. seebergensis deserve special attention. Their stands expand northward their previous range by $16 \mathrm{~km}$ and $30 \mathrm{~km}$, respectively. The stand of $R$. pedemontanus is interesting as well, as it falls into the disjunction zone between areas of high presence of this species in the southern and northern Poland, which may indicate that the gap between these ranges is not clear cut, and to some extent might be related to the fact, that the previous research conducted in this area was insufficient.

\section{REFERENCES}

BANK DanYCH o LaSACH: Nadleśnictwo Durowo (https:// www.bdl.lasy.gov.pl/portal/; created: 2016, acquired: 25.11.2016.

Bator J., GąbKa M., Jakubas E. (2014): Koncepcja lasu modelowego w zarządzaniu i ochronie różnorodności biologicznej rzek Wełny i Flinty (Wielkopolska). [The concept of the model forest in management and biodiversity protection of the Wełna and the Flinta rivers (Wielkopolska Region)]. Bogucki Wydawnictwo Naukowe, Poznań.

Hammer Ø., Harper D.A.T., Ryan P.D. (2001): PAST: Paleontological Statistics Software Package for Education and Data Analysis. Palaeontologia Electronica 4(1): 1-9.

Kondracki J. (2014): Geografia regionalna Polski. Wydawnictwo Naukowe PWN, Warszawa.

Kosiński P. (2006): Current distribution of the recently described bramble species, Rubus guttiferus (Rosaceae), in Poland. Dendrobiology 56: 45-49.

Kosiński P. (2007): Rozmieszczenie oraz warunki występowania drzew i krzewów w polskiej części Sudetów Wschodnich. Acta Botanica Silesiaca, Monographiae 1: 1-404.

Kosiński P. (2010): The genus Rubus in the Bardo Mts (Central Sudetes). Dendrobiology 63: 77-98.

Kosiński P., BeDnorz L. (2003): Trees and shrubs of the Polish part of the eastern Sudety Mts. Dendrobiology 49: 31-42. 
KosińsKi P., CzARna A., MALIŃsKi T. (2014): Rubus occidentalis (Rosaceae) - a new naturalized raspberry species in the Polish flora. Dendrobiology 71: 159-165.

Kosiński P., OKLeJEwicz K. (2006): Rubus parthenocissus (Rosaceae) in Poland. Dendrobiology 55: 33-38.

KosiŃSKI P., ZIELIŃSKI J. (2013): Rubus maximus (Rosaceae) found also in Poland. Botanika-Steciana 17: 33-37.

Kurtto A., Weber H.E., Lampinen R., Sennikov A.N. (eds). (2010): Atlas Florae Europaeae. Distribution of Vascular Plants in Europe. 15. Rosaceae (Rubus). The Committee for Mapping the Flora of Europe \& Societas Biologica Fennica Vanamo, Helsinki.

MALIŃSKI T. (2001): Rodzaj Rubus L. W południowej Wielkopolsce. Rocznik Dendrologiczny 49: 13-95.

MALIŃSKi T., ZielińsKi J., KosińsKi P. (2014): Rubus limitaneus (series Mucronati, subgenus Rubus, Rosaceae) - a species new to science from NW Poland. Dendrobiology 72: 57-64.

MALIŃski T., Zieliński J., Kosiński P. (2015): Rubus lindebergii (Rosaceae) - new species for the flora of Poland. Dendrobiology 74: 143-147.

OKLejewicz K. (2006): Distribution patterns of $R u-$ bus species (Rosaceae) in the eastern part of the Polish Carpathians. Polish Botanical Studies 21: $1-98$.

Oklejewicz K., Trávničé B., Wolanin M. (2013): New localities of Rubus clusii (Rosaceae) seriously expanding its range towards the East. Dendrobiology 70: 93-98.

OlACZeK R. (1974): Kierunki degeneracji fitocenoz leśnych i metody ich badania. Phytocoenosis 3(3/4): 179-190.

Plan Urządzenia Lasu Nadleśnictwa Durowo na okres od 1 stycznia 2012 r. do 31 grudnia 2021 r, z dnia 20 listopada 2011 r. (2011). Biuro Urządzania Lasu i Geodezji Leśnej, Oddział w Poznaniu.
QGIS Development Team (2016): QGIS Geographic Information System. Open Source Geospatial Foundation Project, http://www.qgis.org/ (access: 25.11.2016).

SPRIBILle F. (1902): Verzeichnis der bis zum Herbst 1902 in der Provinz Posen beobachteten Brombeeren. Deutsche Gesellschaft für Kunst und Wissenschaft in Posen, Zeitschrift der Naturwissenschaftlichen Abteilung. Botanik 9(2): 113-148.

Trávniček B., OkLejewicz K., Zieliński J. (2005): Rubus ambrosius (Rubus subsect. Rubus, Rosaceae) a new bramble species from the eastern part of Central Europe. Folia Geobotanica et Phytotaxonomica 40: 421-434.

Wolanin M.M., Wolanin M.N., Musiat K., Kania I., OKLEJEWICZ K. (2016): Rubus zielinskii (Rosaceae) a new species from Poland. Phytotaxa 273(3): 183-190.

ZAJĄC A. (1978): Atlas of distribution of vascular plants in Poland (ATPOL). Taxon 27 (5/6): 481484.

ZiELIŃSKI J. (2004): The Genus Rubus (Rosaceae) in Poland. Polish Botanical Studies 16: 1-300.

ZiELIŃSKi J., Kosiński P., TOMASZEWSKI D. (2004a): Rubus lucentifolius (Rosaceae) - a new species of bramble from Poland. Polish Botanical Journal 49(1): 5-9.

ZIELIŃSKI J., KosińsKi P., ToMAsZEWSKI D. (2004b): The genus Rubus (Rosaceae) in Southeastern Lower Silesia (Poland). Polish Botanical Journal 49: 161-180.

ZielińSKi J., TRÁvNičEK B. (2004): Rubus bohemo-polonicus (Rosaceae) - a new species of bramble from the Czech Republic and Poland. Acta Societatis Botanicorum Poloniae 73(4): 311-314.

For citation: GAPIŃSKA M., KosIŃSKI P. (2016): Rubus flora of the Durowo Forest District (northern Wielkopolska, Poland). Steciana 20(4): 239-249. doi: 10.12657/steciana.020.025 